\title{
PERSEPSI ANGGOTA TERHADAP FUNGSI MAJELIS TAKLIM MASJID JAMI' AL-MUNAWARAH KENAGARIAN GURUN PANJANG KECAMATAN BAYANG KABUPATEN PESISIR SELATAN
}

${ }^{1}$ Reza Gusmanti, ${ }^{2}$ Wirdatul'aini, ${ }^{3}$ Setiawati.

1,2,3 Jurusan Pendidikan Luar Sekolah Fakultas Ilmu Pendidikan Universitas Negeri Padang Rezagusmanti@yahoo.co.id

\begin{abstract}
ABSTRAK
Penelitian ini dilatarbelakangi oleh keberhasilan program Majelis Taklim Masjid Jami' AlMunawarah. Tujuan penelitian mengungkapkan fungsi majelis taklim dalam memberdayakan masyarakat bidang pendidikan, sosial, ekonomi, keagamaan, seni dan budaya, serta ketahanan bangsa. Jenis penelitian deskriptif kuantitatif. Populasi penelitian adalah anggota majelis taklim sebanyak 90 orang dengan 45 orang sebagai sampel. Teknik pengambilan sampel adalah stratified random sampling. Teknik pengumpulan data angket dengan alat pengumpulan data pedoman angket. Teknik analisis data menggunakan perhitungan persentase. Hasil penelitian menunjukkan fungsi majelis taklim dalam memberdayakan masyarakat bidang pendidikan, sosial, ekonomi, keagamaan, seni dan budaya, serta ketahanan bangsa dikategorikan sangat baik, hal ini terlihat dari tingginya persentase jawaban baik dan sangat baik. Dapat disimpulkan fungsi majelis taklim terlaksana dengan baik. Diharapkan kepada pengelola majelis taklim agar dapat meningkatkan fungsi majelis taklim.

Kata kunci : persepsi, majelis taklim
\end{abstract}

\section{ABSTRACT}

This research is background by success of the program taklim in Mosque Jami' AlMunawarah. The purpose decribe adolescent of the functions taklim in the field of education, social, economic, religious, arts and culture, as well as resilience of the nation. The kind of this research is quantitative descriptive. The study population is member taklim 90 person with a sampel 45 person. The sampling technique is stratified random sampling. Data analysis techniques using percentage calculations. The results showed the information of functions taklim of the six categorized were excellent, it is evident from the high percentage of good and very good answers. It can be concluded functions taklim perfoming well. Expected taklim to managers in order to improve the implementation of the functions taklim.

Keywords : perception, function taklim 


\section{PENDAHULUAN}

Pendidikan nonformal mempunyai fungsi utama untuk membina dan meningkatkan kualitas sumber daya manusia di lingkungan masyarakat, lembaga, dan keluarga. Satuan pendidikan nonformal adalah kelompok belajar, kursus-kursus, pelatihan, pusat kegiatan belajar masyarakat dan majelis taklim serta satuan pendidikan sejenis (Sudjana: 2004).

Sadar akan hal tersebut, maka disusunlah berbagi program pendidikan untuk orang dewasa yang berbasis kepada pendidikan pemberdayaan perempuan. Seperti pendidikan kursus untuk kaum Ibu, pendidikan keagamaan yang dilaksanakan pada majelis taklim. Melalui majelis taklim, kaum perempuan diarahkan pada usaha untuk memberikan kegiatan yang lebih bermanfaat. Perempuan memiliki kesempatan untuk ikut serta dalam sejumlah kegiatan keagamaan, organisasi, maupun kegiatan sosial lainnya.

Majelis Taklim Masjid Jami' Al-Munawarah berdiri sejak tahun 2010, di Kenagarian Gurun Panjang Kecamatan Bayang Kabupaten Pesisir Selatan. Majelis taklim ini merupakan satu-satunya majelis taklim yang ada di Kenagarian Gurun Panjang. Kegiatan yang ada dan dilaksanakan pada majelis taklim ini adalah wirid pengajian mingguan, arisan, tadarus, membesuk jika salah seorang anggota dalam keadaa sakit, dan yasinan yang diadakan ketika ada masyrakat yang meninggal dunia.

Berdasarkan hasil wawancara tanggal 07 Agustus 2015, dengan pengurus inti majelis taklim Ibu Herma Rosita S.Ag. bahwa kehadiran anggota Majelis Taklim Masjid Jami' Almunawarah Gurun Panjang mengalami peningkatan pada setiap kegiatan yang di adakan, kehadiran anggota majelis taklim rata-rata di atas $90 \%$ pada setiap kegiatan para anggota majelis selalu mengikuti kegiatan belajar dari awal sampai akhir kegiatan berlangsung, kegiatan yang di laksanakan oleh majelistaklim selalu bervariasi setiap minggunya seperti wirid pengajian mingguan, wirid pengajian bulanan, dakwah karya wisata, arisan, kegiatan sosial dan yasinan. Selanjutnya peneliti melakukan wawancara tanggal 08 Agustus 2015, dengan Ibu Rostanti sebagai anggota majelis taklim bahwa ibu tersebut merasa senang mengikuti majelis taklim, karena kegiatan yang dilaksanakan terdiri dari berbagai macam kegiatan yang dapat membantu ibu tersebut dalam menjalani kehidupanya sehari-hari seperti kegiatan wirid, arisan, dan yasinan.

Berdasarkan fenomena di atas maka peneliti tertarik untuk melakukan penelitian tentang Persepsi Anggota Terhadap Fungsi Majelis Taklim Masjid Jami’ Al-Munawarah Kenagarian Gurun Panjang Kecamatan Bayang Kabupaten Pesisir Selatan. Berdasarkan permasalahan di atas maka dapat di identifikasi masalah sebagai berikut adalah: (1) kegiatan majelis taklim sesuai dengan kebutuhan ibu-ibu anggota majelis taklim, (2) narasumber dalam setiap kegiatan yang di undang tidak membosankan dan berwawasan luas, (3) kehadiran para anggota mejelis dalam mengikuti kegiatan sangat tinggi, (4) dukungan dari pengurus majelis taklim sangat baik, (5) sarana dan prasarana yang tersedia sudah lengkap, (6) suasana nyaman, (7) dukungan dari anggota keluarga cukup tinggi, (8) persepsi anggota terhadap fungsi majelis taklim baik.

Dalam pelaksanaan penelitian ini penulis mempunyai tujuan yang hendak dicapai yaitu: (1) untuk mengetahui persepsi anggota terhadap fungsi majelis taklim dalam bidang pendidikan, (2) untuk mengetahui persepsi anggota terhadap fungsi majelis taklim dalam 
bidang sosial, (3) untuk mengetahui persepsi anggota terhadap fungsi majelis taklim dalam bidang ekonomi, (4) untuk mengetahui persepsi anggota terhadap fungsi majelis taklim dalam bidang keagamaan, (5) untuk mengetahui persepsi anggota terhadap fungsi majelis taklim dalam bidang seni dan budaya, (6) untuk mengetahui persepsi anggota terhadap fungsi majelis taklim dalam bidang ketahanan bangsa.

Adapun manfaat penelitian ini secara teoritis yaitu dapat memberikan sumbangan ilmiah terhadap keilmuan dalam bidang pendidikan luar sekolah khususnya pada bidang pengembangan masyarakat. Manfaat praktis adalah (1) masukan bagi pengelola dan pengurus dalam mensosialisasikan dan pengembangan kegiatan majelis taklim, (2) bagi peneliti untuk menambah pengetahuan dan pengalaman dalam melakukan penelitian baik secara praktik maupun teoritis, (3) bagi peneliti selanjutnya bisa dijadikan sebagai pedoman atau acuan dalam melakukan penelitian.

Adapun defenisi operasional yaitu Muhsin (dalam Rizaldy, 2013), menjelaskan bahwa fungsi majelis taklim adalah (1) fungsi pendidikan, yakni menjadi pusat kegiatan belajar masyarakat (learning society), keterampilan hidup dan berwirausaha, (2) fungsi sosial, yakni menjadi wahana silaturrahmi, menyampaikan gagasan dan sekaligus sarana dialog antara ulama, umara dan umat, (3) fungsi ekonomi, yakni sebagai sarana tempat pembinaan dan pemberdayaan ekonomi jamaah, (4) fungsi keagamaan, yakni membina dan mengembangkan ajaran islam dalam rangka membentuk masyarakat yang beriman dan bertaqwa, (5) fungsi seni dan budaya, yakni sebagai tempat pengembangan seni budaya islam, (6) fungsi ketahanan bangsa, yakni menjadi wahana pencerahan umat dalam kehidupan agama masyarakat dan berbangsa.

\section{KAJIAN TEORI}

Rakhmad (2001), mengemukakan bahwa persepsi sebagai pengalaman individu tentang objek-objek, peristiwa atau hubungan yang diperolehnya dengan menyimpulkan informasi dan penafsiran pesan-pesan. Persepsi yang dimaksud dalam penelitian ini adalah pandangan anggota terhadap fungsi majelis taklim yang terlihat dari bidang pendidikan, sosial, ekonomi, keagamaan, seni dan budaya, dan bidang ketahanan bangsa.

\section{Fungsi Majelis Taklim}

Departemen Pendidikan Nasional (2008:400), fungsi merupakan kegunaan suatu hal. Muhsin (dalam Rizaldy, 2013) menjelaskan bahwa fungsi majelis taklim adalah sebagai, 1) fungsi pendidikan, yakni menjadi pusat kegiatan belajar masyarakat (learning society), keterampilan hidup dan berwirausaha, 2) fungsi sosial, yakni menjadi wahana silaturahmi, menyampaikan gagasan dan sekaligus sarana dialog antara ulama, umara dan umat, 3) fungsi ekonomi, yakni sebagai sarana tempat pembinaan dan pemberdayaan ekonomi jamaah, 4) fungsi keagamaan, yakni membina dan mengembangkan ajaran Islam dalam rangka membentuk masyarakat yang beriman dan bertaqwa, 5) fungsi seni dan budaya, yakni sebagai tempat pengembangan seni budaya Islam, dan 6) fungsi ketahanan bangsa, yakni menjadi wahana pencerahan umat dalam kehidupan beragama masyarakat dan berbangsa.

Fungsi majelis taklim yang dimaksud dalam penelitian ini adalah fungsi majelis taklim yang terlihat dari bidang pendidikan, sosial, ekonomi, keagamaan, seni dan budaya, serta dalam bidang ketahanan bangsa. 


\section{a. Fungsi Majelis Taklim dalam Bidang Pendidikan}

Persepsi anggota terhadap fungsi majelis taklim dalam bidang pendidikan yang dimaksud dalam penelitian ini adalah sebagai berikut.

1) Sebagai Pusat Kegiatan Belajar Masyarakat

Skiner (dalam Soedomo, 2009: 89) menyatakan bahwa kegiatan belajar masyarakat (learning society) adalah pengaturan kondisi yang optimal sehingga mampu menghasilkan perubahan dan proses pembentukannya memerlukan dorongan yang sesuai dengan minatnya. Belajar bersangkutan dengan pertumbuhan intelektual sehingga meningkatkan kemampuan dirinya maupun karena interaksi dengan orang lain.

2) Keterampilan Hidup

Slameto (2010), menjelaskan keterampilan adalah seperangkat kemampuan atau kecakapan yang positif dalam melakukan pelatihan/bimbingan aktivitas dan pengalaman seseorang serta membantunya berkembang dan menyesuaikan diri kepada lingkungan sehingga menghasilkan kepuasan diri.

3) Berwirausaha

Suryana (2008:56) kewirausahaan (entrepreneurship) adalah "kemampuan kreatif dan inofatif yang dijadikan dasar, kiat dan sumber daya untuk mencari peluang menuju sukses."

\section{b. Fungsi Majelis Taklim dalam Bidang Sosial}

Persepsi anggota terhadap fungsi majelis taklim dalam bidang sosial yang dimaksud dalam penelitian ini adalah sebagai berikut.

1) Wahana Silaturahmi

Abdullah (2010:86) "bersilaturahmi dapat memberi manfaat kepada sejumlah orang atau kelompok dengan bersilaturahmi dapat memberikan pengenalan terhadap hal-hal baru dalam menghadapi kehidupan, mendapatkan pengalaman yang bermacam-macam atau wawasan diri, dan dapat menimbulkan cita-cita."

2) Menyampaikan Ide dan Pendapat

Rakhmat (2001:64), menyatakan pendapat adalah pengalaman tentang objek, peristiwa dan hubungan yang diperoleh dengan menyimpulkan informasi dan menafsirkan pesan.

\section{c. Fungsi Majelis Taklim dalam Bidang Ekonomi}

Persepsi anggota terhadap fungsi majelis taklim dalam bidang ekonomi yang dimaksud dalam penelitian ini adalah sebagai sarana pemberdayaan ekonomi jamaah. Ginandjar (1996), pemberdayaan ekonomi rakyat adalah upaya yang merupakan pengarahan sumber daya untuk mengembangkan potensi ekonomi rakyat untuk meningkatkan produktivitas rakyat menuju pembangunan yang lebih maju di masa yang akan datang.

\section{d. Fungsi Majelis Taklim dalam Bidang Keagamaan}

Persepsi anggota terhadap fungsi majelis taklim dalam bidang keagamaan yang dimaksud dalam penelitian ini adalah membina dan mengembangkan ajaran Islam.

Zakiyah (1992), pendidikan Islam adalah suatu bentuk usaha atau proses yang dilakukan untuk menciptakan manusia yang berakidah dan berakhlak mulia yang seutuhnya agar senantiasa dapat memahami ajaran Islam secara menyeluruh, sehingga dapat menghayati 
tujuan yang pada akhirnya dapat mengamalkan serta menjadikan Islam sebagai pandangan hidup.

\section{e. Fungsi Majelis Taklim dalam Bidang Seni Dan Budaya}

Persepsi anggota terhadap fungsi majelis taklim dalam bidang seni budaya yang dimaksud dalam penelitian ini adalah sebagai tempat pengembangan seni dan budaya Islam. Koentjaraningrat (2009:144) mengatakan bahwa "seni merupakan salah satu wujud dari kebudayaan yang bersifat artifact yakni benda-benda hasil karya manusia, di samping dua wujud kebudayaan yang lain yaitu ideas, dan activities."

\section{f. Fungsi Majelis Taklim dalam Bidang Ketahanan Bangsa}

Persepsi anggota terhadap fungsi majelis taklim dalam bidang ketahanan bangsa yang dimaksud dalam penelitian ini adalah sebagai wahana pencerahan umat dalam kehidupan agama masyarakat dan berbangsa. Menurut Asmawi (2001:30) "wahana pencerahan merupakan hikmah yang dapat diambil dari fenomena dan tumbuhnya kesadaran umat Islam untuk memahami ajaran Islam, perubahan perilaku dan sikap oleh umat untuk mendapatkna ajaran Islam yang relevan dengan kondisi sosial dan budaya mereka." Sehingga maksud dari wahana pencerahan itu adalah agar mereka lebih mempunyai kekuatan dan kemampuan dalam menyikapi masalah kehidupannya masing-masing seiring dengan tantangan kehidupan yang semakin kompleks dan berat.

\section{METODOLOGI PENELITIAN}

Penelitian ini merupakan penelitian deskriptif kuantitatif. Populasi dalam penelitian ini adalah seluruh anggota Majelis Taklim Masjid Jami’ Al-munawarah yang berjumlah 90 orang anggota tetap majelis taklim. Dengan rincian sebagai berikut.

Tabel. 1

Populasi Penelitian

\begin{tabular}{|l|c|c|}
\hline No & Pendidikan Terakhir & Populasi \\
\hline 1 & SD & 8 Orang \\
\hline 2 & SMP & 24 Orang \\
\hline 3 & SMA & 46 Orang \\
\hline 4 & D3 & 8rang \\
\hline 5 & SI & Orang \\
\hline \multicolumn{2}{|c|}{ Jumlah } & Orang \\
\hline
\end{tabular}

Sumber Dokumentasi Pimpinan Majelis Taklim Masjid Jami’ Al-Munawarah

Ciri-ciri populasi adalah sebagai berikut.

a. Terdaftar sebagai anggota majelis taklim;

b. Bisa/mampu membaca dan menulis;

c. Mengikuti kegiatan yang dilakukan dalam majelis;

d. Berusia 30 tahun keatas ;

e. Tingkat pendidikan berbeda-beda.

Penarikan sampel dilakukan dengan teknik stratified random sampling. Adapun langkahlangkah pengambilan sampel ini dengan menggunakan teknik stratified random sampling, memisahkan elemen atau unsur-unsur menjadi sub kelompok atau strata, memilih dengan 
simpel random sampling dari tiap strata kemudian membuat daftar sampel yang dipilih, diperoleh sampel penelitian seperti pada tabel tiga berikut ini.

Tabel. 2

Distribusi Sampel Penelitian

\begin{tabular}{|c|c|c|c|}
\hline No & Pendidikan Terakhir & Populasi & Sampel \\
\hline 1 & SD & 8 Orang & 4 orang \\
\hline 2 & SLTP & 24 Orang & 12 orang \\
\hline 3 & SLTA & 46 Orang & 23 orang \\
\hline 4 & D3 & 8 Orang & 4 orang \\
\hline 5 & S1 & 4 Orang & 2 orang \\
\hline & Jumlah & 90 Orang & 45 Orang \\
\hline
\end{tabular}

Sumber: Dokumentasi Pimpinan Majelis Taklim Masjid Jami’ Al-Munawarah

Teknik yang digunakan untuk mengumpulkan data pada penelitian ini adalah angket, sedangkan alat pengumpul data yang digunakan adalah pernyataan. Analisis data dalam penelitian ini untuk menggambarkan pengawasan yang diberikan kepada anggota digunakan rumus persentase.

\section{HASIL DAN PEMBAHASAN}

Persepsi Anggota terhadap Fungsi Majelis Taklim Jami' Al-Munawarah dalam Bidang Pendidikan Sebagai pusat kegiatan belajar masyarakat

Untuk melihat persepsi anggota terhadap fungsi majelis taklim dalam bidang pendidikan dengan sub variabel sebagai pusat kegiatan belajar masyarakat, dapat dilihat dalam histogram berikut.

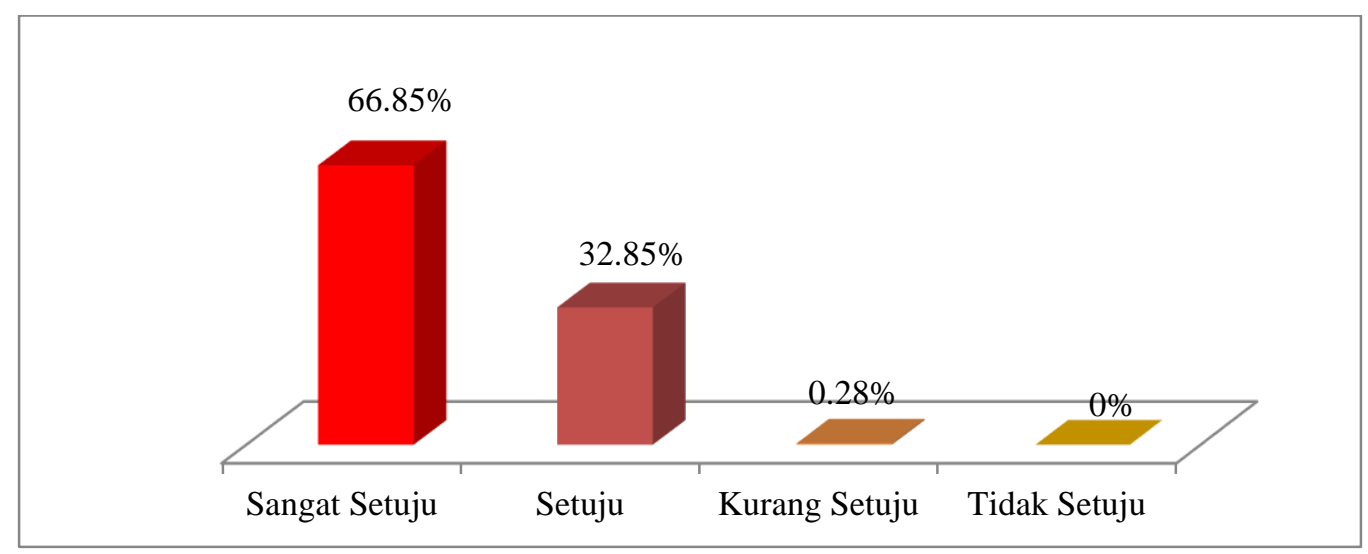

Gambar 1 Histogram distribusi frekuensi fungsi majelis taklim dalam bidang pendidikan sebagai pusat kegiatan belajar masyarakat

Dari histogram di atas dapat disimpulkan bahwa persepsi anggota terhadap fungsi majelis taklim dalam bidang pendidikan sebagai pusat kegiatan belajar masyarakat dilihat dari rekapitulasi jawaban $(66,85 \%)$ responden manyatakan sangat setuju, maka persepsi anggota terhadap fungsi majelis taklim dalam bidang pendidikan sebagai pusat kegiatan belajar masyarakat dapat dikategorikan sangat baik.

\section{Sebagai keterampilan hidup}


Untuk melihat persepsi anggota terhadap fungsi majelis taklim dalam bidang pendidikan dengan sub variabel sebagai keterampilan hidup, dapat dilihat dalam histogram berikut.

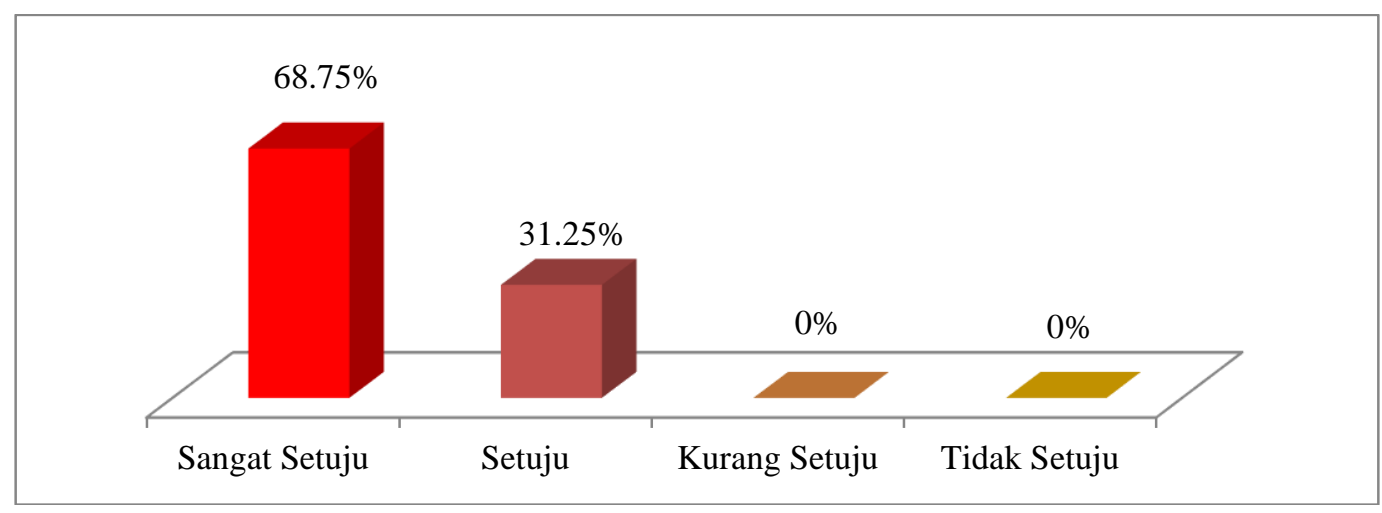

\section{Gambar 2 Histogram distribusi frekuensi fungsi majelis taklim dalam bidang pendidikan sebagai keterampilan hidup}

Dari histogram di atas dapat disimpulkan bahwa persepsi anggota terhadap fungsi majelis taklim dalam bidang pendidikan sebagai keterampilan hidup dilihat dari rekapitulasi jawaban $(66,75 \%)$ responden manyatakan sangat setuju, maka persepsi anggota terhadap fungsi majelis taklim dalam bidang pendidikan sebagai keterampilan hidup dapat dikategorikan sangat baik.

\section{Berwirausaha}

Untuk melihat persepsi anggota terhadap fungsi majelis taklim dalam bidang pendidikan dengan sub variabel sebagai kegiatan berwirausaha, dapat dilihat dalam histogram berikut.

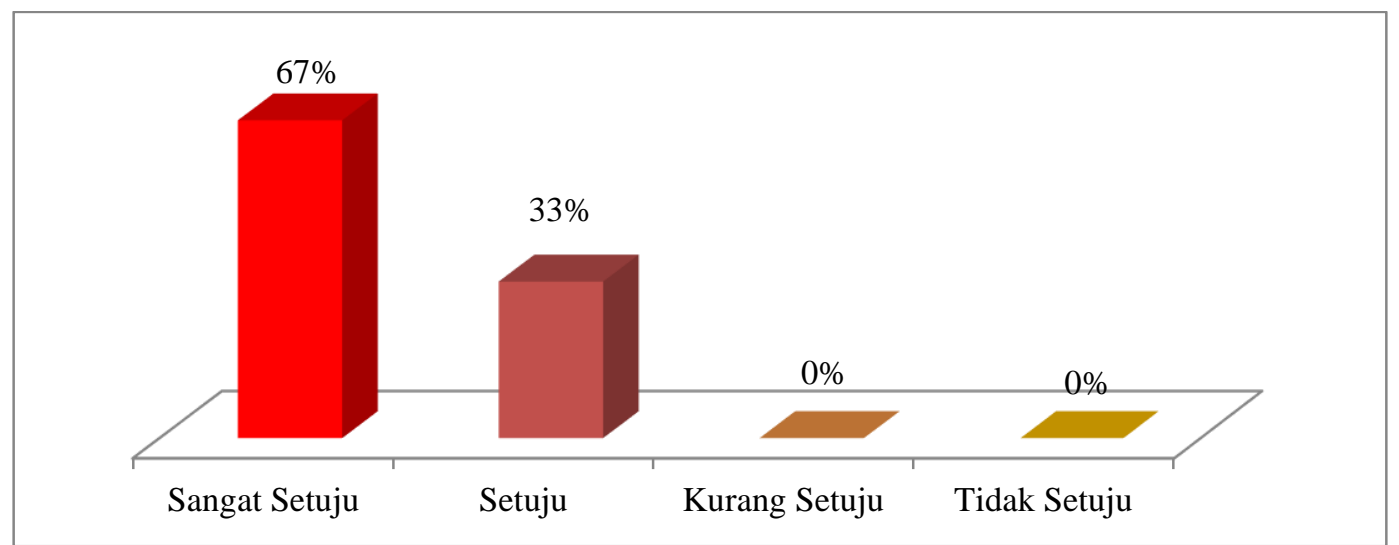

\section{Gambar 3 Histogram distribusi frekuensi fungsi majelis taklim dalam bidang pendidikan sebagai kegiatan berwirausaha}

Dari histogram di atas dapat disimpulkan bahwa persepsi anggota terhadap fungsi majelis taklim dalam bidang pendidikan sebagai kegiatan berwirausaha dilihat dari rekapitulasi jawaban (67\%) responden manyatakan sangat setuju, maka persepsi anggota terhadap fungsi majelis taklim dalam bidang pendidikan sebagai kegiatan berwirausaha dapat dikategorikan sangat baik karena terlihat dari jawaban responden yang memilih jawaban sangat setuju.

Persepsi Anggota terhadap Fungsi Majelis Taklim Masjid Jami' Al-Munawarah dalam Bidang Sosial Sebagai wahana bersilaturrahmi 
Untuk melihat persepsi anggota terhadap fungsi majelis taklim dalam bidang sosial dengan sub variabel sebagai wahana bersilaturrahmi, dapat dilihat dalam histogram berikut

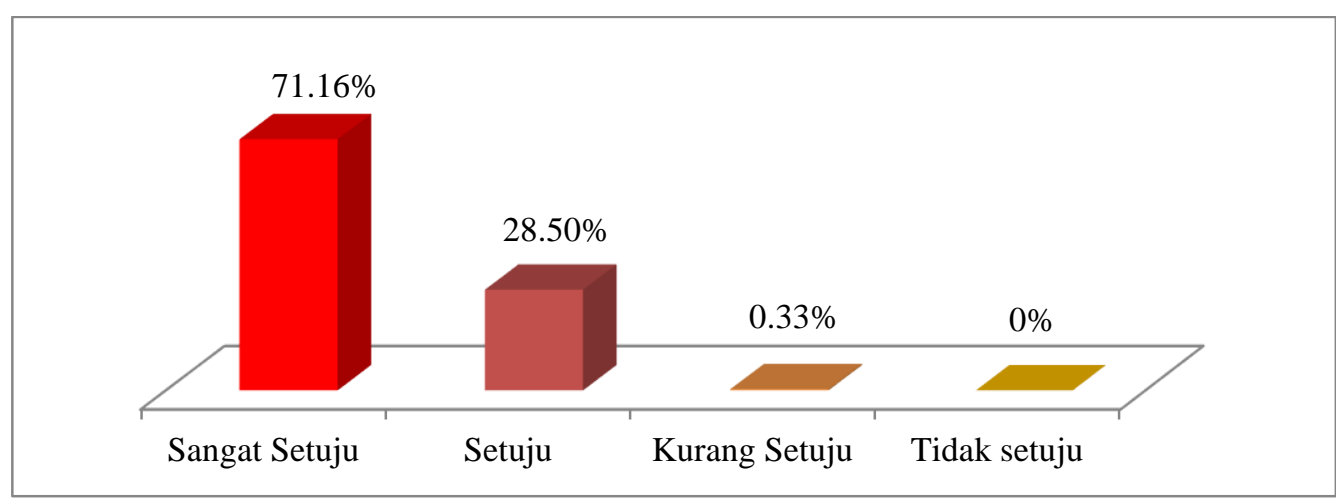

\section{Gambar 5 Histogram distribusi frekuensi fungsi majelis taklim dalam bidang sosial sebagai wahana silaturrahmi}

Dari histogram di atas dapat disimpulkan bahwa persepsi anggota terhadap fungsi majelis taklim dalam bidang sosial sebagai wahana silaturrahmidilihat dari rekapitulasi jawaban $(71,16 \%)$ responden manyatakan sangat setuju, maka persepsi anggota terhadap fungsi majelis taklim dalam bidang sosial sebagai wahana silaturrahmi dapat dikategorikan sangat baik.

\section{Sebagai sarana untuk menyampaikan ide dan pendapat}

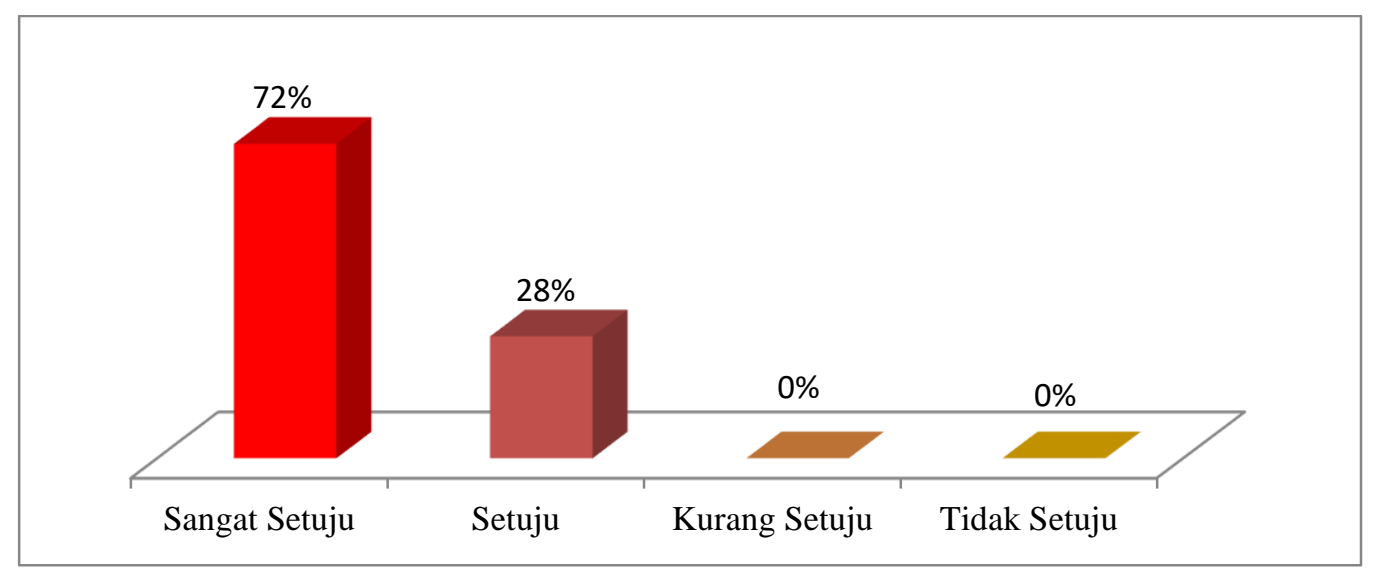
$\begin{array}{ll}\text { Gambar } 6 & \text { Histogram distribusi frekuensi fungsi majelis taklim dalam bidang sosial } \\ \text { sebagai sarana untuk menyampaikan ide dan pendapat }\end{array}$

Dari histogram di atas dapat disimpulkan bahwa persepsi anggota terhadap fungsi majelis taklim dalam bidang sosial sebagai sarana untuk menyampaikan ide dan pendapat dilihat dari rekapitulasi jawaban (72\%) responden manyatakan sangat setuju, maka persepsi anggota terhadap fungsi majelis taklim dalam bidang sosial sebagai sarana untuk menyampaikan ide dan pendapat dapat dikategorikan sangat baik.

\section{Persepsi Anggota terhadap Fungsi Majelis Taklim Jami' Al-Munawarah dalam Bidang Ekonomi Sarana pemberdayaan ekonomi jamaah}

Dari data di atas dapat dijelaskan bahwa persepsi anggota terhadap fungsi majelis taklim dalam bidang ekonomi sebagai sarana pemberdayaan ekonomi jamaah dapat dikatgorikan sangat baik. Untuk lebih jelasnya dapat dilihat dari histogram di samping sebagai berikut. 


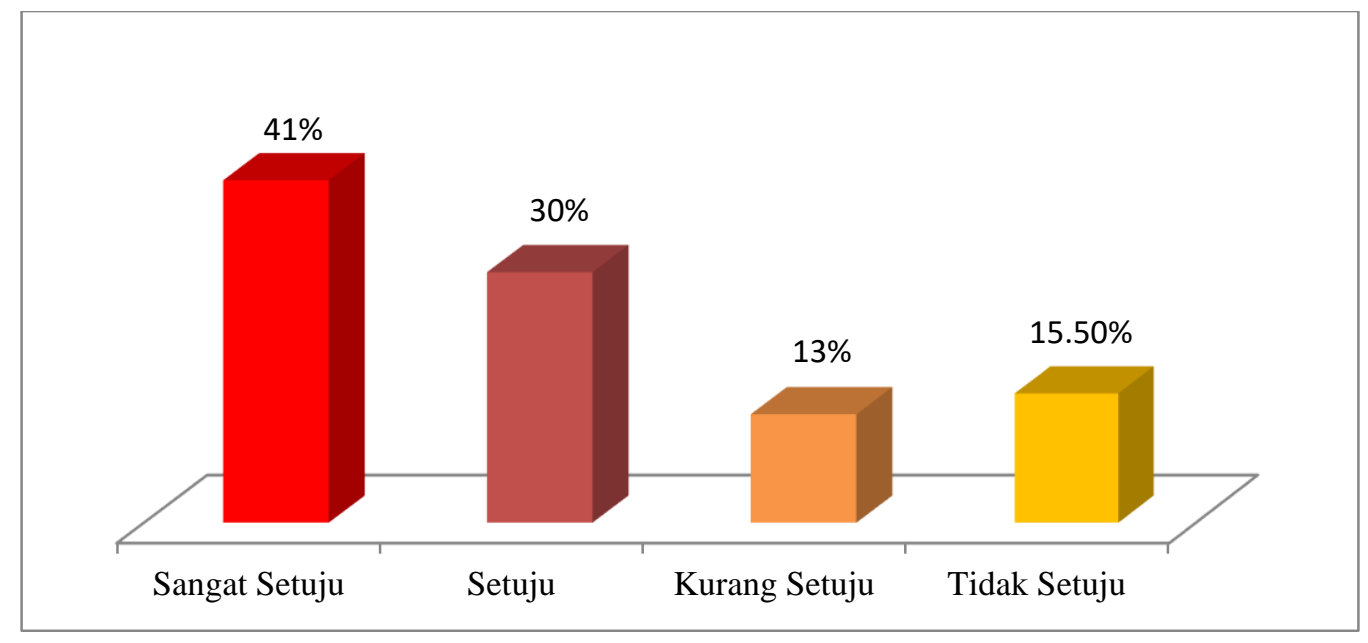

Gambar 7 Histogram distribusi frekuensi fungsi majelis taklim dalam bidang ekonomi sebagai sarana pemberdayaan ekonomi jamaah

Dari histogram di samping dapat disimpulkan bahwa persepsi anggota terhadap fungsi majelis taklim dalam bidang ekonomi sebagai sarana pemberdayaan ekonomi jamaah dilihat dari rekapitulasi jawaban (41\%) responden manyatakan sangat setuju, maka persepsi anggota terhadap fungsi majelis taklim dalam bidang ekonomi sebagai sarana pemberdayaan ekonomi jamaah dapat dikategorikan baik.

\section{Persepsi Anggota terhadap Fungsi Majelis Taklim Jami' Al-Munawarah dalam Bidang Keagamaan Membina dan mengembangkan ajaran Islam}

Dari data di atas dapat dijelaskan bahwa persepsi anggota terhadap fungsi majelis taklim dalam bidang keagamaan sebagai sarana membina dan mengembangkan ajaran islam dapat dikatgorikan sangat baik. Untuk lebih jelasnya dapat dilihat dari histogram di samping sebagai berikut.

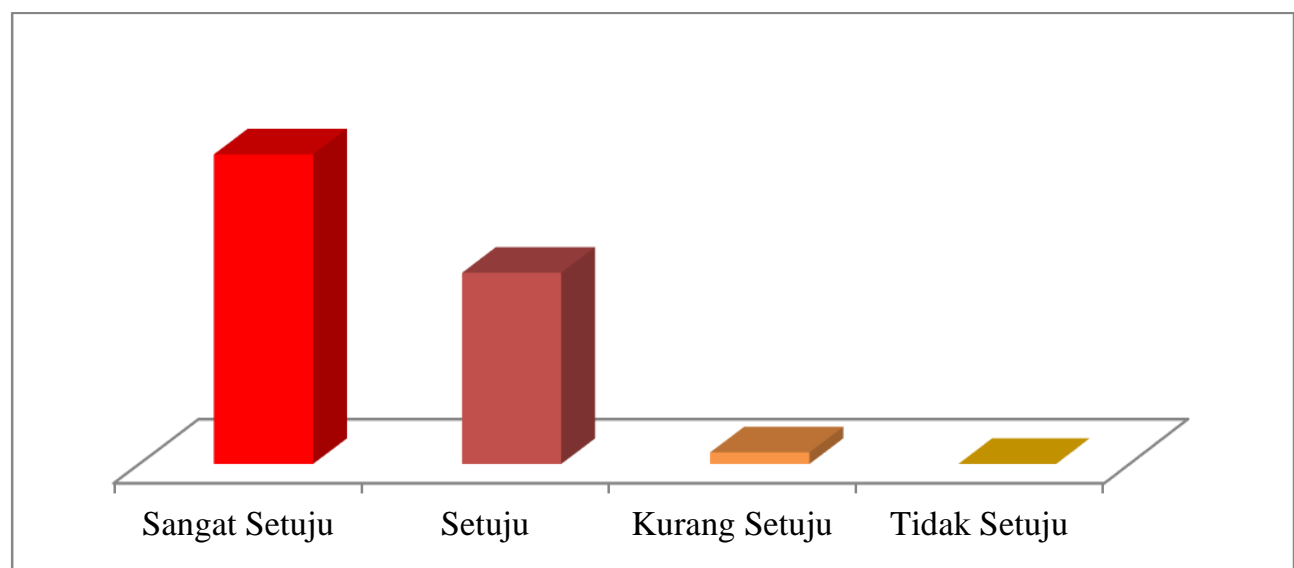

Gambar 8 Histogram distribusi frekuensi fungsi majelis taklim dalam bidang keagamaan sebagai sebagai sarana membina dan mengembangkan ajaran Islam

Dari histogram di samping dapat disimpulkan bahwa persepsi anggota terhadap fungsi majelis taklim dalam bidang keagamaan sebagai sarana sarana membina dan mengembangkan ajaran Islam dilihat dari rekapitulasi jawaban $(60,25 \%)$ responden manyatakan sangat setuju, 
maka persepsi anggota terhadap fungsi majelis taklim dalam bidang keagamaan sebagai sarana membina dan mengembangkan ajaran Islam dapat dikategorikan sangat baik.

Persepsi Anggota terhadap Fungsi Majelis Taklim Masjid Jami’ Al-Munawarah dalam Bidang Seni dan Budaya Sebagai tempat pengembangan seni dan budaya Islam

Dari data di atas dapat dijelaskan bahwa persepsi anggota terhadap fungsi majelis taklim dalam bidang keagamaan sebagai tempat pengembangan seni dan budaya Islam dapat dikatgorikan sangat baik. Untuk lebih jelasnya dapat dilihat dari histogram di samping sebagai berikut.

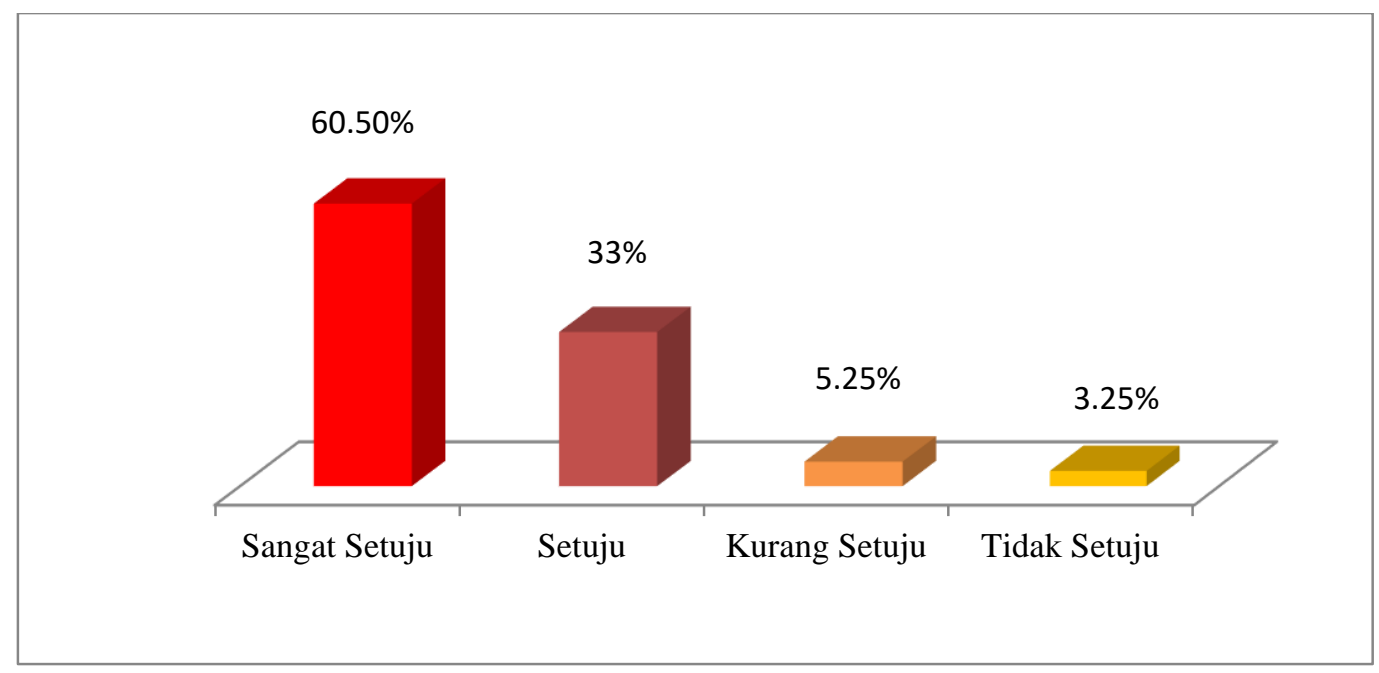

Gambar 9 Histogram distribusi frekuensi fungsi majelis taklim dalam bidang seni dan budaya sebagai tempat pengembangan seni dan budaya Islam

Dari histogram di atas dapat disimpulkan bahwa persepsi anggota terhadap fungsi majelis taklim dalam bidang seni dan budaya sebagai sarana pengembangan ide dilihat dari rekapitulasi jawaban $(60,50 \%)$ responden manyatakan sangat setuju, maka persepsi anggota terhadap fungsi majelis taklim dalam bidang seni dan budaya sebagai tempat pengembangan seni dan budaya islam dapat dikategorikan sangat baik.

Persepsi Anggota terhadap Fungsi Majelis Taklim Masjid Jami’ Al-Munawarah dalam Bidang Ketahanan Bangsa Sebagai sarana pencerahan umat

Dari data di atas dapat dijelaskan bahwa persepsi anggota terhadap fungsi majelis taklim dalam bidang ketahanan bangsa sebagai sarana pencerahan umat dapat dikatgorikan sangat baik. Untuk lebih jelasnya dapat dilihat dari histogram di samping sebagai berikut. 


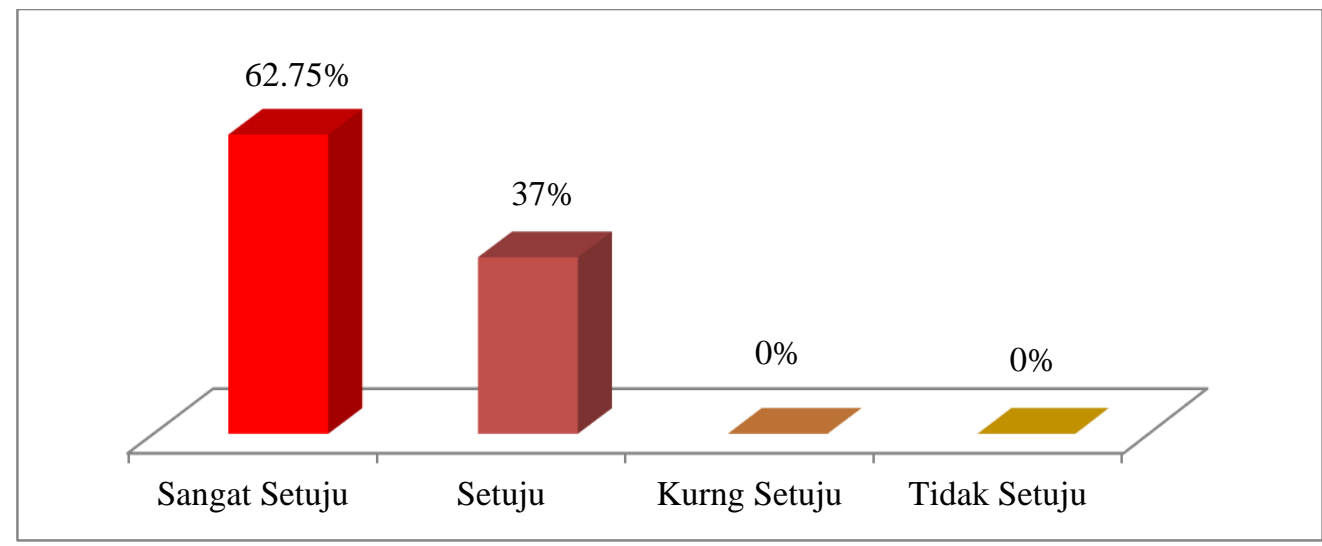

\section{Gambar 10 Histogram distribusi frekuensi fungsi majelis taklim dalam bidang ketahanan bangsa sebagai sarana pencerahan umat dalam kehidupan}

Dari histogram di samping dapat disimpulkan bahwa persepsi anggota terhadap fungsi majelis taklim dalam bidang ketahanan bangsa sebagai sarana pencerahan umat dalam kehidupan dilihat dari rekapitulasi jawaban $(62,75 \%)$ responden manyatakan sangat setuju, maka persepsi anggota terhadap fungsi majelis taklim dalam bidang ketahanan bangsa sebagai sarana untuk pencerahan umat dapat dikategorikan sangat baik.

Persepsi anggota terhadap fungsi majelis taklim juga dapat diolah data menggunakan kelas interval dikarenakan jumlah sampel dan item pernyataan yang banyak. Selain itu, dengan menggunakan kelas interval akan langsung didapatkan perolehan persentase pada setiap kategori. Panjang kelas interval ditentukan melalui selisih antara skor tertinggi dengan skor terendah ditambah dengan 1, dan hasilnya dibagi dengan banyak kelas interval. Data tentang persepsi anggota terhadap fungsi majelis taklim yang berhasil dikumpulkan dari sampel sebanyak 45 orang secara kuantitatif menunjukkan bahwa skor tertinggi adalah 148 dan skor terendah 131. Kelas interval dari pernyatan diatas dikelompokkan menjadi 4 kelas sebagai berikut.

$$
\begin{gathered}
R=\frac{H-L+1}{i} \\
R=\frac{148-131+1}{4} \quad \text { (Sudijono, 2014: 52) } \\
R=5
\end{gathered}
$$

$$
\begin{aligned}
\text { Keterangan }=\mathrm{R} & =\text { Total Range } \\
\mathrm{H} & =\text { Highest Score (Nilai Tertingi) } \\
\mathrm{L} & =\text { Lowest Score (Nilai Terendah) } \\
1 & =\text { Bilangan konstan } \\
\mathrm{I} & =\text { Kelas Interval. }
\end{aligned}
$$

Tabel .3 Kelas Interval persepsi anggota terhadap fungsi majelis taklim

\begin{tabular}{|c|c|c|c|c|}
\hline No & Kelas Interval & F & \% & Kategori \\
\hline 1 & $144-148$ & 13 & $29 \%$ & Sangat Setuju \\
\hline 2 & $139-143$ & 19 & $42 \%$ & Setuju \\
\hline
\end{tabular}




\begin{tabular}{|c|c|c|c|c|}
3 & $134-138$ & 11 & $24 \%$ & Kurang Setuju \\
\hline 4 & $129-133$ & 2 & $4 \%$ & Tidak Setuju \\
\hline
\end{tabular}

Data persepsi anggota terhadap fungsi majelis taklim dapat digambarkan dengan histogram berikut ini.

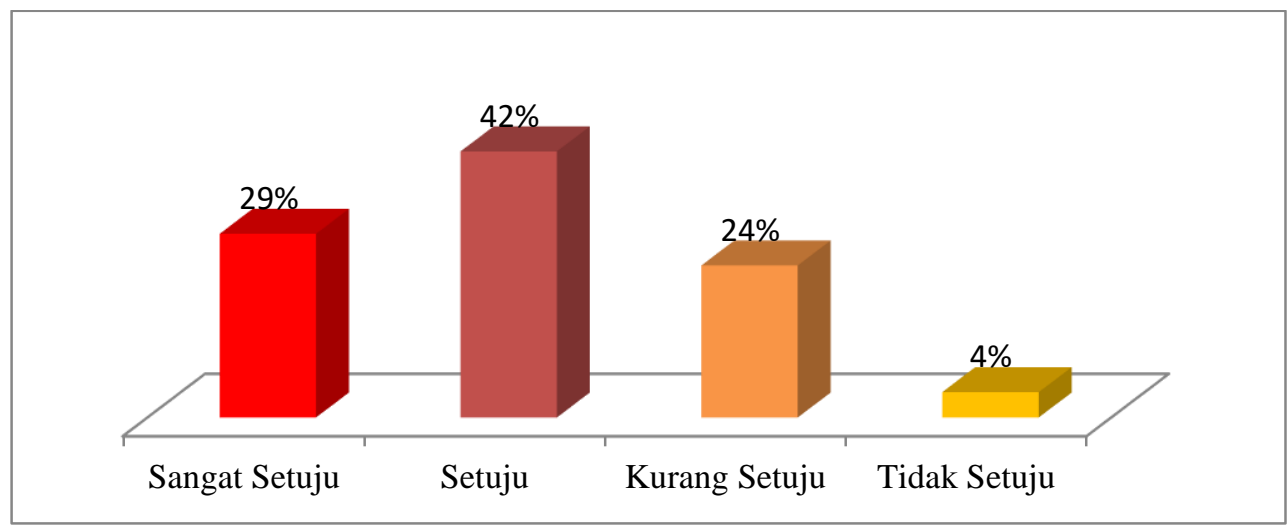

\section{Gamabar. 11 Histogram Distribusi Persepsi anggota terhadap fungsi majelis taklim}

Gambar 11 menunjukkan bahwa persepsi anggota terhadap fungsi Majelis Taklim Masjid Jami' Al-Munawarah sebgaian besar (29\%) berada pada kategori sangat setuju dan (42\%) pada kategori Setuju . Adapun persepsi anggota terhadap fungsi Majelis Taklim Masjid Jami' Almunawarah pada kategori kurang setuju (24\%) dan (4\%) pada kategori tidak setuju. Jadi, Persepsi anngota terhadap fungsi Majelis Taklim Masjid Jami’ Al-munawarah berada pada kategori baik.

\section{PEMBAHASAN}

Pada bagian ini akan dikemukakan pembahasan hasil penelitian tentang persepsi anggota terhadap fungsi majelis taklim di Masjid Jami’ Al-munawarah Kenagarian Gurun Panjang Kecamatan Bayang Kabupaten Pesisir Selatan.

\section{Persepsi Anggota terhadap Fungsi Majelis Taklim Masjid Jami’ Al-Munawarah dalam Bidang Pendidikan Sebagai pusat kegiatan belajar masyarakat}

Berdasarkan temuan penelitian dan hasil pengolahan data sebelumnya maka dijelaskan bahwa persepsi anggota terhadap fungsi majelis taklim dalam bidang pendidikan sebagai pusat kegiatan belajar masyarakat bagi anggota Majelis Taklim Masjid Jami' Al-Munawarah diklasifikasikan pada kategori sangat baik.

Sejalan dengan hal tersebut bahwa majelis taklim sebagai kegiatan belajar di dalam masyarakat adalah bentuk aktif yang dilakukan oleh orang yang ahli dalam memberikan atau mengajarkan ilmu kepada orang lain sehingga terjadi perubahan yang signifikasn dimasa yang akan datang Istikhori (2007:90). Skiner (dalam Soedomo 2009: ) juga menyatakan bahwa kegiatan belajar masyarakat (Learning Society) adalah pengaturan kondisi yang optimal sehingga mampu menghasilkan perubahan dan proses pembentukanya memerlukan dorongan yang 
sesuai dengan minatnya. Belajar bersangkutan dengan pertumbuhan intelektual sehingga meningkatkan kemampuan dirinya maupun karena interaksi dengan orang lain.

Berdasarkan pendapat diatas bahwa persepsi anggota terhadap fungsi majelis taklim sebagai pusat kegiatan belajar masyarakat merupakan salah satu bentuk kiegiatan yang mendidik yang berada di tengah-tengah masyarakat dan bagian yang sangat penting dalam mencerdaskan kehidupan bangsa sehingga mampu menghasilkan perubahan kerarah yang lebih baik untuk di masa yang akan datang sehingga tercipta kehidupan yang harmonis dan rukun antar sesama umat manusia.

\section{Keterampilan hidup}

Berdasarkan temuan penelitian dan hasil pengolahan data sebelumnya maka dijelaskan bahwa persepsi anggota terhadap fungsi Majelis Taklim Masjid Jami' Al-Munawarah dalam bidang pendidikan sebagai keterampilan hidup di diklasifikasikan pada kategori sangat baik. Sejalan dengan itu keterampilan hidup harus dimiliki oleh setiap orang sehingga seseorang tersebut mau dan berani menghadapi problema hidupnya secara wajar tanpa merasa tertekan, kemudian secara proaktif dan kreatif mencari serta menemukan solusi sehingga akhrinya mampu mengatasinya, Slamet (2002: 1).

Jadi keterampilan hidup adalah memberikan kesempatan kepada sesorang untuk memperoleh pengetahuan, pengetahuan untuk bekerja dan berusaha secara mandiri. Berdasarkan pendapat di atas bahwa persepsi anggota terhadap fungsi majelis taklim dalam bidang pendidikan sebagai keterampilan hidup merupakan kemampuan seseorang agar dapat bersosialisasi dengan lingkungan sehingga mampu menghadapi berbagai permasalahan yang dihadapi di dalam kehidupan sehari-hari, untuk itu persepsi anggota terhadap fungsi majelis taklim dalam bidang pendidikan sebagai keterampilan hidup merupakan hal yang penting demi terwujudnya kehidupan masyarakat yang tentram dan nyaman.

\section{Berwirausaha}

Berdasarkan temuan penelitian dan hasil pengolahan data sebelumnya maka dijelaskan bahwa persepsi anggota terhadap fungsi majelis taklim dalam bidang pendidikan sebagai kegiatan berwirausaha dapat diklasifikasikan pada kategori sangat baik. Sejalan dengan itu Thomas W Zimmerer (2005) merumuskan berwirausaha dapat memberi peluang dan kebebasan untuk mengendalikan nasib sendiri memiliki usaha sendiri akan memberikan peluang dan kebebasan untuk mencapai tujuan hidup. Suryana, (2008) kewirausahaan (Entrepreneurship) adalah kemampuan kreatif dan inofatif yang dijadikan dasar, kiat dan sumber daya untuk mencari peluang menuju sukses.

Berdasarkan pendapat di atas bahwa persepsi anggota terhadap fungsi majelis taklim dalam bidang pendidikan sebagai kegiatan berwirausaha merupakan sarana bagi masyarakat untuk mengembangkan kemampun yang dimiliki sehingga mempuyai peluang dan kebebasan agar dapat memanfaatkan sumber daya yang ada sehingga mempunyai kemapuan untuk menjalani kehidupan dan menghadapi tantangan-tantangan yang terjadi di tengah-tengah masyarakat. 


\section{Persepsi Anggota terhadap Fungsi Majelis Taklim Masjid Jami' Al-Munawarah dalam Bidang Sosial Wahana silaturrahmi}

Berdasarkan temuan penelitian dan hasil pengolahan data sebelumnya maka dijelaskan bahwa persepsi anggota terhadap fungsi majelis taklim dalam bidang sosial sebagai wahana silaturrahmi dapat diklasifikasikan pada kategori sangat baik. Sejalan dengan hal tersebut Samarqandi (2005) bersilaturrahmi menyatakan bahwa dengan bersilaturrahmi seseorang (1) Akan mendapat ridho dari Allah SWT, (2) membuat orang yang kita dikunjungi berbahagia, (3) menyenangkan malaikat, (4) Disenangi oleh manusia, (5) membuat iblis dan setan marah, (6) Memanjangkan usia, (7) menambah banyak dan berkah rejekinya, (8) membuat senang orang yang telah wafat.

Abdullah (2010:86) Bersilaturrahmi dapat memberi manfaat kepada sejumlah orang atau kelompok dengan bersilaturrahmi dapat memberikan pengenalan terhadap hal-hal baru dalam menghadapi kehidupan, mendapatkan pengalaman yang bermacam-macam atau wawasan diri, dapat menimbulkan cita-cita.

Berdasarkan pendapat di atas bahwa persepsi anggota terhadap fungsi majelis taklim dalam bidang sosial sebagai wahana silaturrahmi dapat memperoleh ridho dari Allah SWT baik hidup didunia maupun diakhirat kelak, bersilaturrahmi berarti adanya pengenalan hal-hal baru di dalam kehidupan, sehingga diperoleh pengalaman dan wawasan tentang kehidupan. Untuk bersilaturrahmi di dalam majelis taklim merupakan hal yang sangat penting demi terwujud masyarakat yang menjaga hubugan persaudaraan sesama manusia.

\section{Menyampaikan ide dan pendapat}

Berdasarkan temuan penelitian dan hasil pengolahan data sebelumnya maka dijelaskan bahwa persepsi anggota terhadap fungsi majelis taklim dalam bidang sosial sebagai sarana menyampaikan ide dan pendapat terlaksana dengan baik. Salah satu bentuk hak azazi manusia adalah hak untuk berpendapat. Hak untuk bebas berpendapat dan mengeluarkan pikiran, ide, ataupun gagasan ini dimiliki semua orang. Menyampaikan ide dan pendapat harus disampaikan dilandasi niat baik, penuh tanggung jawab. Sejalan dengan hal tersebut Bullatau (2007: 6) menyatakan pemikiran bersama yang mempunyai kemampuan kreatif dalam artian realistis. Oleh karena itu ketika seseorang menyampaikan ide, gagasan dan pendapat sejalan dengan orang lain dalam kelompoknya, maka dapat tercipta dan terbukalah kemungkinan untuk bertindak dengan daya dorong yang lebih kuat berkat kerja sama dan keyakinan bersma.

Menurut UUD 1945 Pasal 28 E berbunyi setiap warga negara berhak untuk menyampaikan aspirasi serta menyuarakan pendapat, ide, gagasan dihadapan umum dan dilindungi menurut undang-undang. Dengan adanya majelis taklim di tengah-tengah masyarakat akan menjadi wadah bagi masyarakat untuk saling bertukar pendapat, ide dan gagasan sehingga dapat menambah pengetahuan masyarakat.

\section{Persepsi Anggota terhadap Fungsi Majelis Taklim Masjid Jami’ Al-Munawarah dalam Bidang Ekonomi}

\section{Sarana pemberdayaan ekonomi jamaah}


Berdasarkan temuan penelitian dan hasil pengolahan data sebelumnya maka dijelaskan bahwa persepsi anggota terhadap fungsi majelis taklim dalam bidang ekonomi sebagai sarana pemberdayaan ekonomi jamaah terlaksana dengan baik. Ginandjar (1996), pemberdayaan ekonomi rakyat adalah upaya yang merupakan pengarahan sumber daya untuk mengembangkan potensi ekonomi rakyat untuk meningkatkan produktivitas rakyat menuju pembangunan yang lebih maju di masa yang akan datang Meningkatkan peran pemberdayaan masyarakat melalui pengembangan potensi ekonomi dan sosial.

Persepsi anggota terhadap fungsi majelis taklim dalam bidang sosial sebagai sarana pemberdayaan ekonomi jamaah dapat meningkatkan penghasilan masyarakat melalui kegiatan pemberdayaan masyarakat melalui pengembangan potensi dan kemampuan masyarakat ke arah yang lebih baik.

\section{Persepsi Anggota terhadap Fungsi Majelis Taklim Masjid Jami’ Al-Munawarah dalam Bidang Keagamaan}

\section{Membina dan mengembangkan ajaran Islam}

Berdasarkan temuan penelitian dan hasil pengolahan data sebelumnya maka dijelaskan bahwa persepsi anggota terhadap fungsi majelis taklim dalam bidang keagamaan sebagai upaya untuk membina dan mengembangkan ajaran islam terlaksana dengan baik. Menurut Departemen Keagamaan RI 2009 memperkuat fungsi majelis taklim sebagai tempat pengajaran agama Islam secara luas, yang meliputi pengkajian tentang pokok-pokok ajaran Islam dan kaitannya dengan persoalan sehari-hari yang dihadapi oleh umat Islam itu sendiri.

Dengan adanya majelis taklim sebagai lembaga pendidikan islam yang berkembang di tengah-tengah masyarakat, dapat membina dan mengembangkan ajaran islam bagi masyarakat yang ingin mendalami ilmu agama, oleh karena itu fungsi majelis taklim dalam bidang keagamaan sangat penting agar dapat meningkatkan keimanan dan ketaqwaan kepada allah SWT.

\section{Persepsi Anggota terhadap Fungsi Majelis Taklim Masjid Jami' Al-Munawarah dalam} Bidang Seni dan Budaya

Sebagai tempat pengembangan seni dan budaya Islam

Berdasarkan temuan penelitian dan hasil pengolahan data sebelumnya maka dijelaskan bahwa persepsi anggota terhadap fungsi majelis taklim dalam bidang seni dan budaya sebagai tempat pengembangan seni dan budaya islam terlaksana dengan baik. Koentjaraningrat (2009:144) seni merupakan salah satu wujud dari kebudayaan yang bersifat artifact yakni benda-benda hasil karya manusia. dismaping dua wujud kebudayaan yang lain yaitu ideas, dan activities.

Berdasarkan pendapat diatas bahwa salah satu fungsi majelis taklim dalam bidang seni dan budaya yaitu sebagai tempat pengembangan seni dan budaya islam merupakan hal yang sangat penting dalam mengembangkan dan menciptakan hasil-hasil pikiran manusia yang dijadikan sebagai karya.

\section{Persepsi Anggota terhadap Fungsi Majelis Taklim Masjid Jami’ Al-Munawarah Dalam Bidang Ketahanan Bangsa}

Wahana pencerahan umat 
Berdasarkan temuan penelitian dan hasil pengolahan data sebelumnya maka dijelaskan bahwa persepsi anggota terhadap fungsi majelis taklim dalam bidang ketahanan bangsa sebagai wahana pencerahan umat dalam kehidupan agama masyrakat dan berbangsa terlaksana dengan baik.

Menurut Asmawi (2008:30) menyatakan wahana pencerahan merupakan hikmah yang dapat diambil dari fenomena dan tumbuhnya kesadaran umat islam untuk memahami ajaran islam, perubahan perilaku dan sika poleh umat untuk mendapatkna ajaran islam yang relevan dengan kondisi sosial dan budaya mereka. Berdasarkan pendapat di atas persepsi anggota terhadap fungsi majelis taklim dalam bidang ketahanan bangsa sebagai wahana pencerahan umat sangat berguna bagi masyarakat dalam mencapai kemakmuran dan ketentraman hidup di dunia ini.

\section{KESIMPULAN}

Berdasarkan hasil penelitian dan pembahasan, maka dapat ditarik beberapa kesimpulan, yaitu: (1) Fungsi majelis taklim dalam bidang pendidikan dapat dklasifikasikan sangat baik. Hal ini terlihat dari jawaban responden yang menyatakan sangat baik, (2) Fungsi majelis taklim dalam bidang sosial dapat dklasifikasikan sangat baik. Hal ini terlihat dari jawaban responden yang menyatakan sangat baik, (3) Fungsi majelis taklim dalam bidang ekonomi dapat dklasifikasikan baik. Hal ini terlihat dari jawaban responden yang menyatakan sangat baik (4) Fungsi majelis taklim dalam bidang keagamaan dapat dklasifikasikan sangat baik. Hal ini terlihat dari jawaban responden yang menyatakan sangat baik, (5) Fungsi majelis taklim dalam bidang sosial dan budaya dapat dklasifikasikan sangat baik. Hal ini terlihat dari jawaban responden yang menyatakan sangat baik, (6) Fungsi majelis taklim dalam bidang ketahanan bangsa dapat dklasifikasikan sangat baik. Hal ini terlihat dari jawaban responden yang menyatakan sangat baik

\section{SARAN}

Merujuk pada kesimpulan, ada beberapa saran yang dapat dikemukakan dalam penelitian ini, (1) kepada anggota Majelis Taklim Masjid Jami' Al-Munawarah Kenagarian Gurun Panjang Kecamatan Bayang Kabupaten Pesisir Selatan agar mempertahankan penerapan fungsi majelis taklim yang telah terlaksana dengan baik, (2) kepada pengurus Majelis Taklim Masjid Jami' Al-Munawarah Kenagarian Gurun Panjang Kecamatan Bayang agar memfasilitasi anggota majelis taklim dalam penerapan fungsi majelis taklim, (3) diharapkan pada penelitian yang lain agar dapat melihat beberapa faktor lain yang belum diteliti dalam penelitian ini.

\section{DAFTAR PUSTAKA}

Abdul, Aziz. (2010). Panduan Penyusunan Proposal Penelitian Dengan Mudah. Padang: Yayasan Jihadul Khair Center.

Abdullah, Safarina (2010). Sosilogi Pendidikan (Individu, Masyarakat Dan Pendidikan). Jakarta Utara: Rajawali Press.

Asmawi. (2001). Penilaiaan Hasil Belajar. Jakarta: Departemen Pendidikan Nasional. 
Depertemen Keaagama RI. (2009). Alquran dan Terjemahannya. Semarang: Toha Putra.

Departemen Pendidikan Nasional. (2002). Kamus Besar Bahasa Indonesia. Edisi Ketiga Jakarta: Depdiknas.

Istikhori, Ahmad. (2007). Pendidikan Agama Islam Dalam Majelis Taklim Kaum Ibu RW 01 Kelurahan Tegal Parang Jakarta Selatan.

Koentaraningrat. (2009).Pengantar Antropologi. Jakarta: Rineka citra.

Muhsin. (2009). Manajemen Majelis Taklim. Jakarta: Pustaka Intermasa.

Slamet, Juli Joemirat. (2002). Kesehatan Lingkungan. Jakarta: Gajah mada University Press.

Soedomo. (2009). Pendidikan Luar Sekolah Ke Arah Pengembangan Sistem Belajar Masyarakat. Jakarta: Departemen Pendidikan dan Kebudayaan Direktorat Jendral Pendidikan Tinggi Proyek Pengembangan Lembaga Pendidikan Tenaga kependidikan.

Sudjana. S. (2004). Pendidikan Non Formal. Bandung: Falah Production.

Suryana. (2008). Kewirausahaan, Pedoman Praktis, Kiat dan Proses Menunju Sukses, Edisi Revisi, Jakarta: Salemba Empat.

Thomas, W, Zimmerer. (2008). Pengantar Kewirausahaan \& Manajemen Bisnis Kecil, Jakarta: Salemba Empat.

Undang-undang dasar 1945 Pasal 28 E.

Yusuf, Muri. (2005). Metodologi Penelitian. Padang: UNP Press. 